\title{
Identificação dos citoplasmas "S", "T" e "N" via PCR em populações de cebola no Vale do São Francisco
}

\author{
Carlos Antonio F Santos ${ }^{1}$; Daniela L Leite ${ }^{2}$; Nivaldo D Costa ${ }^{1}$; Valter R Oliveira ${ }^{3}$; Ierla Carla N dos \\ Santos ${ }^{4}$; Marciene A Rodrigues ${ }^{4}$

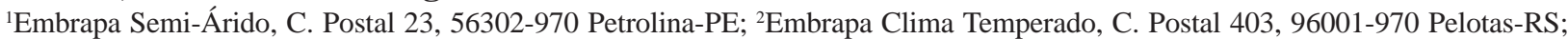 \\ ${ }^{3}$ Embrapa Hortaliças, C. Postal 218, 70359-970 Brasília-DF; ${ }^{4}$ Bolsistas Embrapa Semi-Árido; casantos@cpatsa.embrapa.br; \\ daniela@cpact.embrapa.br; valter@cnph.embrapa.br
}

\section{RESUMO}

A identificação do tipo de citoplasma em cebola foi facilitada com a publicação de primers de DNA específicos para os tipos "S", "T" e "N". O objetivo do presente trabalho foi identificar, por meio de marcadores moleculares, o tipo de citoplasma presente na cultivar de cebola BRS São Francisco e numa população experimental em desenvolvimento na Embrapa Semi-Árido, de forma a orientar o desenvolvimento de híbridos de cebola adaptados à região. Na amostra de 19 plantas da 'BRS Alfa São Francisco' observou-se a amplificação de fragmentos de $180 \mathrm{pb}$, ausência do fragmento de $414 \mathrm{pb}$ com os primers 5' cob e a amplificação do fragmento de 473 pb dos primers OrfA501, indicando que o citoplasma presente nesta população é o citoplasma T. Foi também identificada a presença de citoplasma N na população BRS Alfa São Francisco. Na amostra de 44 plantas da população experimental cascuda-bronzeada observouse a amplificação de produtos consistentes com os fragmentos de 180 e 414 pb dos primers 5' cob, bem como a amplificação de fragmento de 473 pb dos primers OrfA501, indicando que o citoplasma presente na população é o citoplasma $S$. Não foi identificada a presença de citoplasma $\mathrm{N}$ na população cascuda-bronzeada. Estes resultados indicam a possibilidade do desenvolvimento de híbrido tropical, tendo como base a cultivar BRS Alfa São Francisco, enquanto que, na população cascuda-bronzeada será necessário a introgressão do citoplasma "N" para o desenvolvimento de linhagens mantenedoras.

\begin{abstract}
Identification of "S", "T" and "N" cytoplasm via PCR in onion populations in the Sao Francisco river Valley, Brazil

The identification of the onion cytoplasm was obtained by the development of DNA specific primers to "S", "T" and "N" types. The goal of this work was the identification of the cytoplasm type in two different onion populations in the São Francisco river Valley, in order to facilitate the development of onion hybrids from Northeast Brazil. In the sample of 19 plants of the BRS Alfa São Francisco cultivar was observed the amplification of fragments of $180 \mathrm{bp}$ and absence of the fragment of $414 \mathrm{bp}$ of the 5' $\mathrm{cob}$ primers and the presence of fragment of $473 \mathrm{bp}$ of the orfA501 primers, indicating that the cytoplasm of the population is the " $T$ ". Plants with cytoplasm $\mathrm{N}$ were also identified in the BRS Alfa São Francisco population. The amplification of consistent fragments with the 180 and 414 bp of 5' $c o b$ primers was observed in the sample of 44 plants of a Valenciana type population and, the presence of a fragment of 473 bp of orfA501 primers, indicating that the cytoplasm of the population is the "S". No plant with cytoplasm $\mathrm{N}$ was identified in the Valenciana population. The development of a tropical onion hybrid is possible, based on the BRS Alfa São Francisco cultivar, while in the Valenciana type, the introgression of $\mathrm{N}$ cytoplasm will be necessary.
\end{abstract}

Keywords: Allium cepa, male-sterility, PCR, hybrids.

Palavras-chave: Allium cepa, macho-esterilidade, PCR, híbrido.

(Recebido para publicação em 26 de novembro de 2006; aceito em 4 de julho de 2008)

$\mathrm{N}$ o Nordeste, mais especificamente nos estados da Bahia e Pernambuco, são produzidas cerca de 185 mil toneladas de cebola por ano, o que equivale a cerca de $18 \%$ da produção nacional, numa área de aproximadamente 10 mil ha. Mais de 70.000 pessoas da região, direta e indiretamente, vivem desta cultura. O programa de melhoramento genético de cebola da Empresa Pernambucana de Pesquisa Agropecuária (IPA), iniciado em 1972, resultou na substituição de cerca de $90 \%$ das sementes importadas usadas na região (Costa et al., 1999), tendo-se con- centrado no desenvolvimento de populações de cebola amarela e de cebola roxa.

Dowker (1990) relata que a produtividade dos híbridos de cebola tem sido de até $192 \%$ em relação ao parental mais produtivo e de até $367 \%$ em relação a algumas cultivares de polinização aberta. Apesar desta superioridade, o plantio de híbridos de cebola é bastante reduzido no Nordeste brasileiro, em conseqüência do alto preço das sementes, que é pelo menos quatro vezes maior que o das sementes de cultivares de polinização aberta. A maioria dos híbri- dos foi desenvolvida em outros países, podendo apresentar suscetibilidade a doenças, como o mal-de-sete-voltas, causado pelo fungo Colletotrichum gloeosporioides.

Os sistemas de macho-esterilidade gênico-citoplasmáticas (CMS) são a base para a produção de híbridos de cebola, que requer a identificação de linhagens macho-estéreis, linhagens mantenedoras da macho-esterilidade e de linhagens polinizadoras com boa capacidade de combinação, sendo essas linhagens conhecidas como A, B e C, respectivamente. Linhagens macho-es- 
téreis (Smsms) podem ser mantidas por sementes quando cruzadas com uma linhagem mantenedora, a qual possui citoplasma normal $(\mathrm{N})$ para macho-fertilidade e genótipo msms para o loco restaurador da fertilidade, no sistema CMS-(S) descrito por Jones \& Clarke (1943).

Em adição ao citoplasma $\mathrm{N}$ machofértil, três outros macho-estéreis foram identificados em cebola: a) $\mathrm{S}$ - identificado na população Italian Red; b) C identificado na população Rijnsburger; e c) T-identificado na população Jaune paille des vertus (Breninger, 1965). A fertilidade é restaurada por um alelo dominante (Ms) no sistema CMS-(S) e por três loci que segregam independentemente no sistema CMS-(T) (Havey, 1995). Apenas os sistemas CMS-(S) e o CMS-(T) são usados para a produção comercial de híbridos (Engelke et al., 2003). Pouco tem sido reportado sobre o sistema CMS-(C) (Szklarczyk et al., 2002).

A identificação de diversos tipos de citoplasma associados à macho-esterilidade em cebola foi facilitada com a aplicação de marcadores de DNA utilizando-se a PCR (Polymerase Chain Reaction) (Havey, 1995; Sato, 1998; Engelke et al., 2003). O marcador orfA501 (Engelke et al. 2003), que foi desenvolvido a partir de uma seqüência especifica para identificação de citoplasma macho estéril em cebolinha, é amplificado na presença dos citoplasmas $\mathrm{S}$ e $\mathrm{T}$ em cebola, mas não na presença do citoplasma N, macho fértil. Utilizando-se a combinação dos marcadores 5' cob (Sato, 1998) e orfA501 pode-se distinguir entre os três citoplasmas ( $\mathrm{S}, \mathrm{T}$ ou $\mathrm{N}$ ) em plantas individuais poucas semanas após a semeadura (Engelke et al., 2003).

O sistema de macho-esterilidade gênico-citoplasmática (CMS), baseado no citoplasma $\mathrm{S}$, vem sendo utilizado há muito tempo, seja com os laboriosos e demorados cruzamentos testes de campo, ou com apoio de reações de PCR pós 1998. Porém, dados de CMS com citoplasma T são raros, pois até 2003 não era possível distinguir o citoplasma $\mathrm{T}$ do citoplasma $\mathrm{N}$ por métodos moleculares.

O objetivo do presente trabalho foi identificar, por meio de marcadores moleculares, o tipo de citoplasma presente na cultivar de cebola BRS Alfa São Francisco e numa população experimental de cebola, em desenvolvimento na Embrapa Semi-Árido e Hortaliças, de forma a orientar e facilitar o desenvolvimento de híbridos de cebola para o Nordeste do Brasil.

\section{MATERIAL E MÉTODOS}

Foram analisadas plantas de duas populações de cebola, como descrito:

População da 'BRS Alfa São Francisco' - foram analisadas 19 plantas de um segundo cruzamento teste para macho-esterilidade. Para formação dos pares no campo adotou-se o procedimento descrito por Banga \& Petit (1958), que consiste na identificação de plantas estéreis e cruzamento controlado ao acaso com a umbela de uma planta fértil. $\mathrm{Na}$ observação visual das inflorescências no campo foram identificados pares, entre os quais o par P16E1 x P16F1, que apresentava a situação necessária para a produção de híbridos de cebola, qual seja: 1) planta machoestéril produzindo progênies macho-estéreis, resultantes do cruzamento com a planta macho-fértil ou mantenedora da macho-esterilidade, e 2) planta machofértil ou mantenedora produzindo progênies macho-férteis. As plantas analisadas foram provenientes dos seguintes cruzamentos testes: a) do cruzamento teste P16E1 (estéril) x P16F1 (fértil) foram avaliados os pares $6 \mathrm{E}$ (estéril) $\mathrm{x}$ $6 \mathrm{~F}$ (fértil), 7E x 7F, 5E x 5F e as plantas $17 \mathrm{E}, 18 \mathrm{E}, 16 \mathrm{~F}, 14 \mathrm{~F}$ e $15 \mathrm{~F}$; b) de outros cruzamentos testes os pares $3 \mathrm{E} \times 3 \mathrm{~F}, 4 \mathrm{E}$ x 4F 3 e 8E x 8F (Fig. 1).

População experimental cascudabronzeada - foram analisadas ao acaso 44 plantas, sem seleção prévia para macho-esterilidade. Esta população é resultado da seleção de quinze bulbos, efetuada dentro de uma população segregante 'Baia' x 'Valcatorce'.

DNA genômico total foi isolado de folhas de cebola, segundo protocolo CTAB 2x (Doyle \& Doyle, 1990): em torno de 0,2 $\mathrm{g}$ de folhas, mantidas a $-80^{\circ} \mathrm{C}$, foram pulverizadas na presença de nitrogênio líquido em almofariz de porcelana, tratados previamente em ácido clorídrico $3 \mathrm{~N}$. O pó foi transferido para uma solução extratora de $0,9 \mathrm{~mL}$ de CTAB 2\% (500 mM Tris pH 8,0; 1,4 $\mathrm{M} \mathrm{NaCl}$; CTAB $2 \%(\mathrm{p} / \mathrm{v}) ; 0,2 \% \beta-$ mercaptoethanol; $20 \mathrm{mM}$ de EDTA) e incubado a $65^{\circ} \mathrm{C}$ por 50 minutos. O precipitado contendo o DNA total foi colocado para secar à temperatura ambiente, adicionando-se em seguida $120 \mu \mathrm{L}$ de tampão TE (Tris 0,1 M, EDTA 0,01 $\mathrm{M}, \mathrm{pH} 8,0$ ) para armazenamento a $-20^{\circ} \mathrm{C}$. A integridade do DNA total, após tratamento com RNAse, foi observada em gel de agarose $1,5 \%$.

As reações de PCR, que seguiram a metodologia sugerida por Engelke et al. (2003), foram realizadas para um volume final de $25 \mu \mathrm{L}$, contendo $0,25 \mu \mathrm{M}$ de cada primer, $150 \mathrm{mM}$ de cada dNTP, 1,5 $\mu \mathrm{M}$ de $\mathrm{MgCl}_{2}, 0,2$ unidades da enzima DNA polimerase da Biomettrix na solução tampão recomendada pelo fornecedor e $50 \mathrm{ng}$ de DNA total. Os primers usados para a identificação dos citoplasmas foram os publicados por Sato (1998), marcador 5' cob: primer $\mathrm{S}$ específico: 5' GTCCAGTTCCTATAGAACCTATCACT3'; primer $\mathrm{N}$ específico: 5'TCTAGATGTCGCATCAGTGGAATCC3'; primer comum: 5' CTTTTCTATGGTGACAACTCCTCTT3', que amplificam os fragmentos de 180 pb e 414 pb; e os publicados por Engelke et al. (2003), denominados como marcador orf501A: primer 1: 5'ATGGCTCGCCTTGAAAGAGAGC3', primer 2: 5'CCAAGCATTTGGCGCTGAC-3', que amplificaram o fragmento de $473 \mathrm{pb}$. As reações com os marcadores 5' cob constaram de: a) um ciclo inicial de 2,0 minutos a $94^{\circ} \mathrm{C}$, b) 40 ciclos de: 30 segundos a $94^{\circ} \mathrm{C}, 1,0$ minuto a $53^{\circ} \mathrm{C}$ e 2,0 minutos a $72^{\circ} \mathrm{C}$, e c) um ciclo final de 5 minutos a $72^{\circ} \mathrm{C}$. Para os marcadores orf501A adotou-se: a) um ciclo inicial de 2,0 minutos a $94^{\circ} \mathrm{C}$, b) 40 ciclos de: 30 segundos a $94^{\circ} \mathrm{C}, 1,0$ minuto a $60^{\circ} \mathrm{C}$ e 2,0 minutos a $72^{\circ} \mathrm{C}$, e c) um ciclo final de 5 min a $72^{\circ} \mathrm{C}$.

A identificação de citoplasmas $\mathrm{N}, \mathrm{S}$ e T baseou-se em Engelke et al. (2003): 1) citoplasma $\mathrm{N}$ - presença do fragmento de 180 pb e ausência dos demais fragmentos; 2) citoplasma $\mathrm{S}$ - presença dos fragmentos de 180 pb, 414 pb e 473 pb; e 3) citoplasma $\mathrm{T}$ - presença dos fragmentos de 180 pb e de 473 pb e ausência do fragmento de $414 \mathrm{pb}$. 


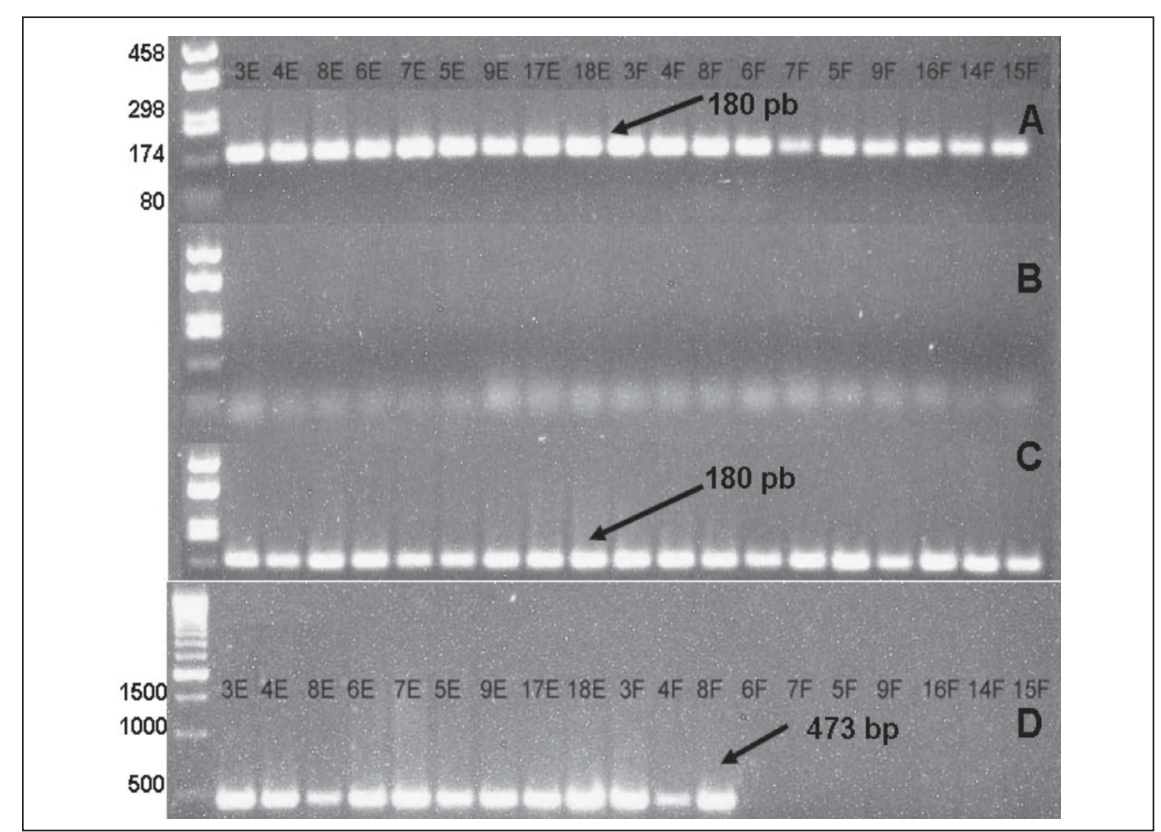

Figura 1. Fragmentos de 19 amostras de cebola de 'BRS Alfa São Francisco' amplificados com os primers 5' cob (painéis A, B e C) e primers orf A501 (painel D). A primeira coluna do lado esquerdo é o padrão de 50 pb da Amresco DNA MicroMarker (painéis A, B e C) e padrão de 500 da Invitrogen (painel D), com os tamanhos das bandas em pares de bases (pb)(Fragments of 19 samples of 'BRS Alfa São Francisco' onion plants amplified with the primers 5' cob (panels A, B and C) and primers orf A501 (panel D). The left first column is the Amresco 50 bp DNA marker size (panels A, B, and C) and the Invitrogen 500 bp DNA marker size (panel D)). Petrolina, PE, Embrapa Semi Arido, 2006.

\section{RESULTADOS E DISCUSSÃO}

O procedimento de seleção para planta macho-estéril em campo resultou na formação de 90 pares entre plantas macho-estéreis e plantas macho-férteis, numa freqüência de, aproximadamente, $2 \%$ de plantas macho-estéreis dentro da população 'BRS Alfa São Francisco' e de 1,7 inflorescência/planta macho-estéril.

Da amostra de 19 plantas da 'BRS Alfa São Francisco' observou-se a amplificação dos fragmentos de $180 \mathrm{pb}$ em todas as plantas (Fig. 1A e 1C), ausência do fragmento de $414 \mathrm{pb}$ em todas as plantas (Fig. 1B) e a amplificação do fragmento de $473 \mathrm{pb}$ (2003) nas nove plantas estéreis e em três férteis $(3 \mathrm{~F}, 4 \mathrm{~F}$ e 8F) (Figura 1D), indicando que o citoplasma presente nesta população é o citoplasma T. Identificou-se a presença de citoplasma $\mathrm{N}$ em sete plantas, todas provenientes da planta fértil do par P16E1 x P16F1 (Fig. 1D). A seleção assistida pelos marcadores moleculares possibilitou a eliminação de plantas que clusivamente macho-estéreis. Estes resultados indicam que a introdução de citoplasma $\mathrm{N}$ na população cascudabronzeada deverá ser feita de outros genótipos para o desenvolvimento de linhagens B ou mantenedora da machoesterilidade.

Apenas duas reações de PCR são necessárias para a correta identificação do citoplasma $\mathrm{T}$ ou $\mathrm{S}$ : uma com os primers $\mathrm{N}+\mathrm{S}+$ Comum de Sato (1998) e outro com os dois primers publicados por Engelke et al. (2003) (Figura 2). As reações com as combinações dos primers do Sato permitiram apenas a confirmação da eficiência da reação de PCR com os três primers nas plantas da 'BRS Alfa São Francisco', não se observando nenhuma amplificação indesejada, seja devido a pareamento entre primers ou amplificação preferencial de outros segmentos não específicos de DNA (Fig. 1).

Ao contrário de Szklarczyk et al. (2002), que trabalharam com DNA mitocondrial, não foi observada nenhuma banda "fantasma" nas reações de PCR realizadas com DNA total (nuclear + mitocondrial + cloroplasto), com o marcador 5' cob, nas duas populações de cebola, confirmando os resultados de Engelke et al. (2003). Esses dados sugerem que os 40 ciclos de PCR foram suficientes para amplificar a pequena quantidade do DNA mitocondrial, onde a mutação para a macho-esterilidade citoplasmática é encontrada, não sendo necessário os laboriosos e onerosos protocolos para extração de DNA do citoplasma, conforme demonstrado originalmente por Engelke et al. (2003).

Os resultados apresentados concordam parcialmente com os obtidos por Leite (1999), que trabalhando com a caracterização molecular citoplasmática da cultivar Alfa Tropical, através de polimorfismos nos DNAs de cloroplasto que distinguem citoplasma $\mathrm{N}$ e $\mathrm{S}$, pela técnica de RFLP, encontrou a presença apenas do citoplasma N. No presente trabalho foi utilizada a população 'BRS Alfa São Francisco', que foi derivada de 'Alfa Tropical', sendo encontrado 12 de 19 plantas com citoplasma T. Apesar destes dados não serem passiveis de comparação direta, evidencia-se a utilidade de PCR com os primers descritos 
por Engelke para revelar a presença de plantas com citoplasma T. Além disso, a técnica de PCR é mais barata e menos laboriosa que RFLP.

Nas condições tropicais do semi-árido brasileiro é possível um ciclo de semente a semente em um ano, considerando quatro meses para a obtenção do bulbo, três meses para vernalização dos bulbos em câmara fria e outros quatro meses do plantio dos bulbos para obtenção de sementes. A identificação da mantenedora dentro da 'BRS Alfa São Francisco' foi possível num período de três anos associando-se seleção visual e pareamento ao acaso (Banga \& Petiet, 1958), com reações de PCR para a identificação do tipo de citoplasma presente nos pareamentos formado em campo. A utilização da técnica de PCR numa população de cebola já florescendo em campo, pode reduzir este tempo para dois anos.

\section{AGRADECIMENTOS}

Os autores agradecem ao BNBETENE-Fundeci pela concessão de recursos financeiros para a execução do presente trabalho.

\section{REFERÊNCIAS}

BANGA O; PETIET J. 1958. Breeding male sterile lines Dutch onion varieties as. preliminary to the breeding of hybrid varieties. Euphytica 7: 21-30.

BERNINGER E. 1965. Contribution à l'étude de la sterilité mâle de l'oignon (Allium cepa L.). Ann Amélior Plant 15:183-199.

COSTA ND; CANDEIA JA; ARAÚJO MT. 1999. Importância econômica da cebola no Nordeste. In: QUEIROZ MA, GOEDERT CO, RAMOS SRR (eds). Recursos Genéticos e Melhoramento de Plantas para o Nordeste Brasileiro. Disponível em: www.cpatsa.embrapa.br/catpub. Acessado em 15 de maio de 2006.

DOYLE JJ; DOYLE JL. 1990. Isolation of plant DNA from fresh tissue. Focus 12: 13-15.

ENGELKE T; TEREFE D; TATLIOGLU T. 2003. A PCR-based marker system monitoring CMS-(S), CMS- (T) and (N)-cytoplasm in the onion (Allium cepa L.). Theoretical and Applied Genetics, 107: 162-167.

DOWKER BD. 1990. Onion Breeding. In: RABINOWITCH HE; BREWSTER JL (eds). Onions and Allied Crops. (eds.). baton Route: CRC Press.

HAVEY MJ; BARK OH. 1994. Molecular confirmation that sterile cytoplasm has been introduced into open-pollinated Grano onion cultivars. Journal of the American Society for Horticultural Science 119: 90-93.

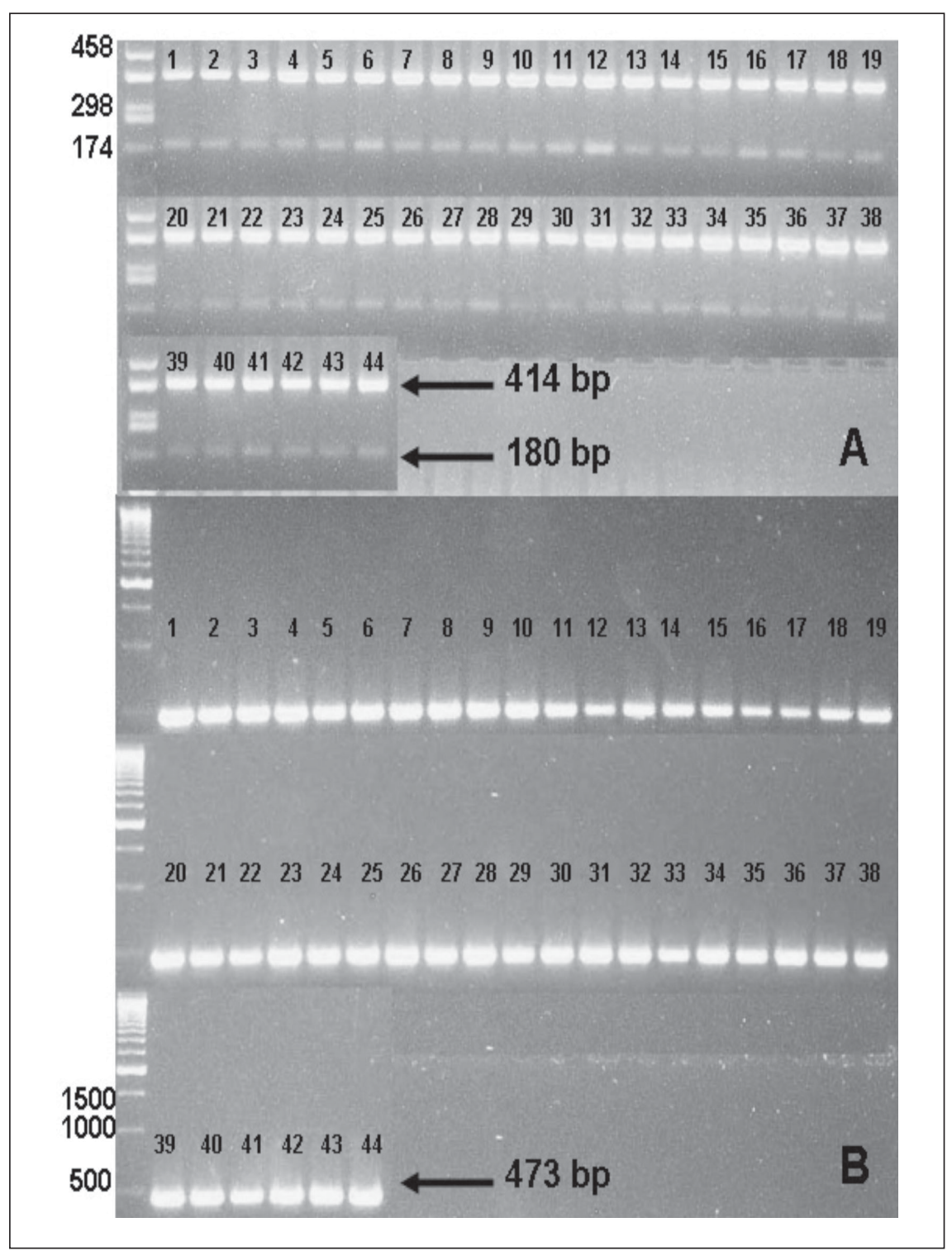

Figura 2. Fragmentos de 44 amostras de cebola de uma população cascuda bronzeada amplificados com os primers 5' cob (painel A) e primers orfA501 (painel B). A primeira coluna do lado esquerdo é o padrão de 50 pb da Amresco DNA MicroMarker (painel A) e padrão de 500 da Invitrogen (painel B), com os tamanhos das bandas em pares de bases (pb)(Fragments of 44 samples of 'Valenciana' type onion plants amplified with the primers 5' cob (panel A) and primers orfA501 (panel B). The left first column is the Amresco 50 bp DNA marker size (panel A) and the Invitrogen 500 bp DNA marker size (panel B)). Petrolina, PE, Embrapa Semi Arido, 2006.

HAVEY MJ. 1995. Identification of cytoplasm using the polymerase chain reaction to aid in the extraction of maintainer lines from openpollinated populations of onion. Theoretical and Applied Genetics 90: 263-268.

JONES H; CLARKE A. 1943. Inheritance of male sterility in the onion and the production of hybrid seed. Proceedings of the American Society for Horticultural Science 43: 189-194.

LEITE DL. 1999. Molecular characterization of cytoplasmic diversity in leek and southamerican onion cultivars and sequencing of onion cDNAs. Madison: University of Wisconsin (Tese doutorado).
SZKLARCZYK M; SIMLAT M; JAGOSZ B; BAG. 2002. The use of cytoplasmic markers in onion hybrid breeding. Cellular \& Molecular Biology Letters 7: 625-634.

SATO Y. 1998. PCR amplification of CMSspecific mitocondrial nucleotide sequences to identify cytoplasmic genotypes of onion (Allium cepa L.). Theoretical and Applied Genetics 96: 367-370. 